\title{
Transgênicos: a visão de alunos do ensino fundamental de uma escola do município de Jaciara-MT sobre os alimentos geneticamente modificados
}

\author{
GM: the elementary school students in view of a school of Jaciara-MT municipality on \\ genetically modified foods
}

Dionísio Garcia de Souza ${ }^{1}$, Leonice Alves Bezerra ${ }^{1}$, Jorge Luiz da Silva ${ }^{2}$ e Simone da Silva Santos ${ }^{1}$

${ }^{1}$ Graduado, Núcleo Avançado de Jaciara, Instituto Federal de Educação, Ciência e Tecnologia de Mato Grosso - Campus São Vicente, Jaciara, MT, Brasil

${ }^{2}$ Mestre (professor), Núcleo Avançado de Jaciara, Instituto Federal de Educação, Ciência e Tecnologia de Mato Grosso Campus São Vicente, Jaciara, MT, Brasil

\begin{abstract}
Resumo
Este trabalho foi realizado com o intuito de sensibilizar e informar os alunos do Ensino fundamental da Escola Estadual Santo Antônio, localizada na cidade de Jaciara-MT, sobre os organismos geneticamente modificados (OGMs) ou simplesmente, os transgênicos. Para isso, mostrou-se aos educandos a presença dos transgênicos na vida cotidiana das pessoas, principalmente na alimentação. Dentro deste contexto, explicou-se os conceitos relacionados ao assunto, tais como o entendimento sobre a estrutura do DNA (ácido desoxirribonucleico) e transgenia. Buscou-se o entendimento do assunto por meio de aulas expositivas e dialogadas, onde foram aplicados questionários, com o objetivo de avaliar o conhecimento prévio dos alunos. Também foram realizadas atividades lúdicas (como jogos de quebra-cabeça, cartas e montagens) e práticas (extração do DNA da cebola). Vale ressaltar que em cada atividade, eram abertos os debates, verificando a sensação e reação dos discentes, analisando o nível de aprendizagem. Como resultado, percebeu-se que a inserção a atividades práticas, lúdicas e dinâmicas, torna o aprendizado mais eficiente e prazeroso, fazendo com que o momento da aula seja melhor aproveitado, evidenciando a obtenção de resultados satisfatórios dentro do ensino de Ciências, e quais as vantagens de trabalhá-las na Educação Básica.
\end{abstract}

Palavras-chave: Transgênicos. DNA. Alunos. Ensino.

\begin{abstract}
This work was carried out in order to raise awareness and inform students of elementary education at the State St. Anthony School, located in Jaciara-MT, on genetically modified organisms (GMOs) or simply GMOs. For this, he showed up to students the presence of GMOs in everyday life of people, mainly in food. Within this context, explained the concepts related to the subject, such as the understanding of the structure of DNA (deoxyribonucleic acid) and transgenesis. We looked up the subject of understanding through exhibition and dialogued classes, where questionnaires were applied in order to assess students' prior knowledge. Also play activities were carried out (like puzzle games, card and assemblies), practical (onion DNA extraction). It is noteworthy that in every activity, discussions were open, checking the feel and response of students, and making meaningful learning. As a result, it was noticed that the inclusion of practical, playful and dynamic activities makes the most efficient and enjoyable learning, making the time during the lesson is better spent, demonstrating the satisfactory results within the Natural Science Education, and the suggesting about methodologies directed to practical activities, and the advantages of working them in Basic Education.
\end{abstract}




\section{Introdução}

Segundo dados da Organização das Nações Unidas, a população mundial chegará a 9,6 bilhões de pessoas em 2050 (ONU, 2012). Com todo este crescimento, um dos grandes desafios é a produção alimentícia. Desde a década de 1950, surgiram estudos avançados visando o aumento da produção de alimentos, criando plantas que fossem mais resistentes às variações, como pragas, ervas daninhas e insetos.

Com o passar dos anos, foram aperfeiçoadas várias técnicas de manipulação e seleção genética. Primeiramente, iniciou-se com os vegetais, em seguida também na área animal. Em 1990 foi apresentada uma variedade de soja que continha sua estrutura genética alterada, e logo após, houve uma demanda de outros alimentos, como milho e arroz. Estes novos produtos foram denominados "Organismos Geneticamente Modificados" (OGMs), ou simplesmente transgênicos.

Por se tratar de um tema direta ou indiretamente presente na vida das pessoas, faz-se necessário uma discussão do assunto, principalmente nas escolas, sendo trabalhado em sala de aula, ultrapassando o senso comum, aumentando a investigação científica e sensibilizando o cidadão. Por exemplo, no conhecimento de leis, como o decreto $\mathrm{n}^{\mathrm{o}} 4.680$, de 24 de abril de 2003, que visa regulamentar a rotulagem dos produtos transgênicos, atendendo às exigências do código de defesa do consumidor, pois alimentos que sejam produzidos a partir de matéria prima oriunda de transgênicos ou contenham traços do mesmo, devem ser rotulados.

O professor deve praticar um ensino de Ciências de qualidade, proporcionando ao aluno entendimento sobre os fenômenos da natureza, por meio de atividades científicas e tornando o ambiente escolar mais atrativo. Desta maneira será possível formar cidadãos mais críticos e com capacidade de julgamento das situações cotidianas.

Ressalta-se a importância do auxílio do professor com influências e interferências planejadas, pois na escola o aluno tem o contato social necessário para promoção da criatividade, desenvolvendo sua parte intelectual, entendendo a evolução da humanidade e o papel destas transformações na sociedade.

A exposição da Ciência, com atividades práticas e dinâmicas, torna a aprendizagem significativa, não sendo apenas o senso crítico desenvolvido, mas também transformando informação em conhecimento.

O objetivo deste trabalho é analisar qual o conhecimento dos alunos do ensino fundamental da Escola Estadual Santo Antônio, situada na cidade de Jaciara-MT, sobre os transgênicos, sua presença no dia-a-dia e principalmente na alimentação. Trata-se de uma investigação, avaliando conceitos sobre noção de genética básica e opiniões sobre o assunto, através de aula conceitual e práticas pedagógicas englobando conhecimentos sobre DNA (ácido desoxirribonucleico) e formação dos transgênicos. Faz-se necessário da mesma forma, investigar quais são as dúvidas dos alunos a respeito do tema, suas opiniões e conhecimentos prévios.

\section{Os Transgênicos no dia-a-dia}

A genética é a área da Biologia que estuda os genes, os mecanismos de transmissão das características hereditárias de pais para filhos ao longo das gerações e inclui a área de manipulação dos genes, conhecida por engenharia genética (LAURENCE, 2005).

Neste processo o DNA, carrega todas as informações genéticas necessárias para formação de um determinado ser (MENDONÇA, 2005).

De acordo com Laurence (2005), a molécula de DNA consiste em duas fitas pareadas formadas por uma sequência de nucleotídeos, opostas quimicamente uma a outra, as duas fitas formam uma dupla hélice. A descoberta desta molécula foi de grande importância para a ciência, pois nela estão contidas as informações fundamentais dos seres vivos.

Os Nucleotídeos são constituídos de um grupamento fosfato, um açúcar e uma base nitrogenada, das quais, na estrutura do DNA, existem 4 tipos: Guanina (G), Citosina (C), Timina (T) e Adenina (A), 
que são fundamentais no estudo da biotecnologia (RIDLEY, 2006).

Neste sentido com Rosa (2012), conceitua a biotecnologia como o conjunto de técnicas de manipulação de organismos vivos, com o intuito de obter produtos específicos ou modificações específicas, através de uma técnica denominada DNA recombinante. A biotecnologia já era utilizada desde os primórdios, na produção de pães e bebidas, porém de forma artesanal, atualmente utiliza técnicas e materiais avançados.

Com o aparecimento de estudos na área de microbiologia e biologia molecular, foi possível manipular microrganismos e genes, com isso, elaborando novos medicamentos e alimentos. Rosa (2012) ainda ressalta que a biotecnologia engloba conhecimentos em diversas áreas, como bioquímica, microbiologia, genética, biologia molecular e química, e com adição da informática, ciência e tecnologia teve-se avanços significativos nos últimos anos.

Segundo Mascarenhas et al. (2012), os transgênicos são organismos que tem um ou mais genes inseridos por manipulação, isso só foi possível após o desenvolvimento da técnica do DNA recombinante (resultado da união de dois fragmentos de DNA).

Por meio da engenharia genética, ou tecnologia do DNA - recombinante, pode-se manipular o padrão de proteínas em um determinado organismo, pela recombinação de seus genes. Novos genes podem ser adicionados, ou genes existentes modificados, para serem ativados em momentos, tecidos ou quantidades diferentes (ALMEIDA e LAMOUNIER 2005).

Pode-se considerar que a engenharia genética, por meio do DNA recombinante deu origem aos transgênicos, e segundo Monquero (2005), os primeiros experimentos realizados com transgênicos em campo foram em 1986, mais precisamente nos Estados Unidos e França. Até o ano de 2003 as pesquisas abrangeram grãos e cereais (soja, milho, arroz e centeio), frutas (maçã, uvas, kiwi, melão, mamão, pêra, morango), óleos (canola, soja e girassol) e hortaliças (aspargo, cenoura, couve-flor, pepino, alface, batata, batata doce, repolho e aipo). As características mais analisadas foram: a tolerância a herbicidas, resistência a insetos, qualidade sensorial e organoléptica do produto final e resistência a vírus e bactérias.

Azeredo (2003) relata que o arroz transgênico, denominado arroz dourado, ajuda a suprir a deficiência de vitamina $\mathrm{A}$, pois foi modificado para produzir betacaroteno, sendo uma alternativa para regiões onde existe deficiência desta vitamina. Valois (2003) ressalta que o feijão também está sendo pesquisado pela EMBRAPA.

Para Mendonça (2005) o emprego de transgênicos em nosso cotidiano tem sido alvo de discussões, porém muitos organismos geneticamente modificados já estão presentes em nosso dia-a-dia a mais tempo do que imaginamos, como é o caso da insulina produzida por uma bactéria geneticamente modificada, e que adota um gene humano, outro caso é a vacina contra hepatite $B$, adquirida através de manipulação de um vírus.

Para Martins (2003) e Pinheiro, Matos e Bazzo (2007), por se tratar de um assunto amplo, não se pode deixar de fazer parte das salas de aulas, pois professores alunos e comunidade em geral devem buscar conhecer melhor as novas tecnologias existentes, que fazem parte de nossas vidas, e estão presentes no cotidiano.

Os Parâmetros Curriculares Nacionais da Educação (PCN's, 1997), afirmam este pensamento, relatando que se tenha metodologias voltadas à construção de conhecimento, estimulando o aluno a um pensar reflexivo, tirando-o do senso comum, e trazendo-o para um conhecimento relacionado ao social e científico, pois o ensino de Ciências visa o desenvolvimento da capacidade de compreender a natureza, o ser humano e a sociedade.

\section{Metodologia}

O estudo foi realizado entre os meses de janeiro e fevereiro de 2014 na escola Estadual Santo Antônio, localizada no município de Jaciara-MT, com alunos de 3 turmas do ensino fundamental (7.․, 8. $\mathrm{o}$ e 9. $\mathrm{o}$ anos), totalizando 58 alunos em geral.

Para o estudo foram realizadas aulas teóricas ( 3 em cada turma) e oficinas didático-pedagógicas direcionadas e focadas no assunto DNA e alimentos transgênicos. A pesquisa constou das seguintes 
etapas:

\subsection{Aplicação de questionário}

Foi utilizado um questionário, em um primeiro momento, verificando os conhecimentos prévios e opiniões dos alunos. O questionário constou de 06 perguntas: a primeira, de múltipla escolha, sobre a utilidade dos transgênicos, e as demais de sim ou não, versando sobre o acompanhamento de notícias referentes aos alimentos transgênicos, os recursos destinados à pesquisa, os impactos ambientais, a rotulagem dos alimentos e por último, com relação à utilização destes alimentos na ração para animais.

\subsection{Aulas}

Foram realizadas aulas teóricas, expositivas e dialogadas, versando sobre o funcionamento e transmissão de características genéticas, e qual o papel do DNA neste processo, para assim poder explicar como se forma um transgênico. Também nestas aulas foram realizadas atividades práticas e dinâmicas.

\subsection{Dinâmica 1: Quebra-cabeça}

Confeccionou-se um quebra cabeça com as letras inicias das bases nitrogenadas formadoras da cadeia de DNA: A (adenina) e T (timina), G (guanina) e C (citosina), para isto aproveitou-se as peças de um quebra-cabeças (adquirido no comércio), fazendo uma adaptação, onde foram marcados com caneta as letras supracitadas, representando as bases (Figuras 1a e 1b). Os alunos foram divididos em grupos de aproximadamente 6 membros, e foi solicitado para que montassem, uma sequência da cadeia do DNA (encaixando as peças, de acordo com a ligação entre as bases) de animais e frutas (estes representados por seus respectivos desenhos), formando o DNA da maçã, da banana, do porco e do sapo.

Em seguida os alunos atribuíram características aos elementos, não fugindo das características básicas inerentes a cada ser, no caso das frutas (cor, sabor e aroma) e no caso dos animais (tamanho, peso e comportamento) (levando em consideração o conceito de que cada "trinca de pares de bases nitrogenadas" são responsáveis por uma característica), e após isso, realizaram a troca destas "trincas" entre as cadeias de DNA dos seres, simulando como a biotecnologia, transfere características de um ser para outro sem que se perda a sua identidade.

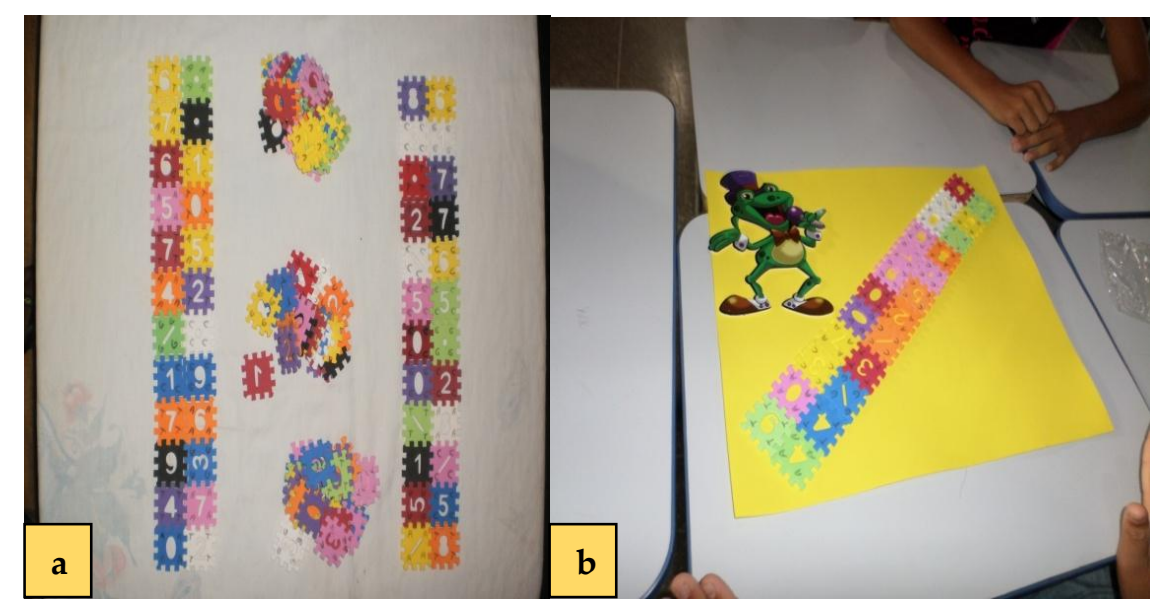

Figura 1 - a) Peças do quebra cabeça confeccionado; b) Desenho do sapo e parte da estrutura do DNA representada no quebra-cabeças 


\subsection{Dinâmica 2: Estrutura de DNA com jujubas}

Consistiu na formação da estrutura do DNA com jujubas coloridas, arames de caderno e recortes circulares de capas de caderno. Foi elaborada uma legenda das bases nitrogenadas de acordo com as cores das jujubas, que eram de quatro cores (cada uma representando uma base nitrogenada) distintas: amarelo, laranja, vermelho e verde.

\subsection{Dinâmica 3: Extração do DNA da cebola}

Realizou-se a prática de extração de DNA da cebola, para isto, utilizou-se os seguintes materiais: álcool, gelo, cebola, sal de cozinha, detergente incolor, béqueres, filtro de papel, banho Maria. Primeiramente, picou-se e macerou-se a cebola, em seguida a cebola macerada foi colocada em um recipiente com detergente $(10 \mathrm{~mL})$, misturado com sal de cozinha (1 colher de sopa) e água $(20 \mathrm{~mL})$, sendo homogeneizado. Em seguida colocou-se o recipiente em banho Maria à $65^{\circ} \mathrm{C}$ por vinte minutos e posteriormente submeteu ao banho de gelo (Figuras 2a, 2b, 2c, 2d, 2e e 2f).

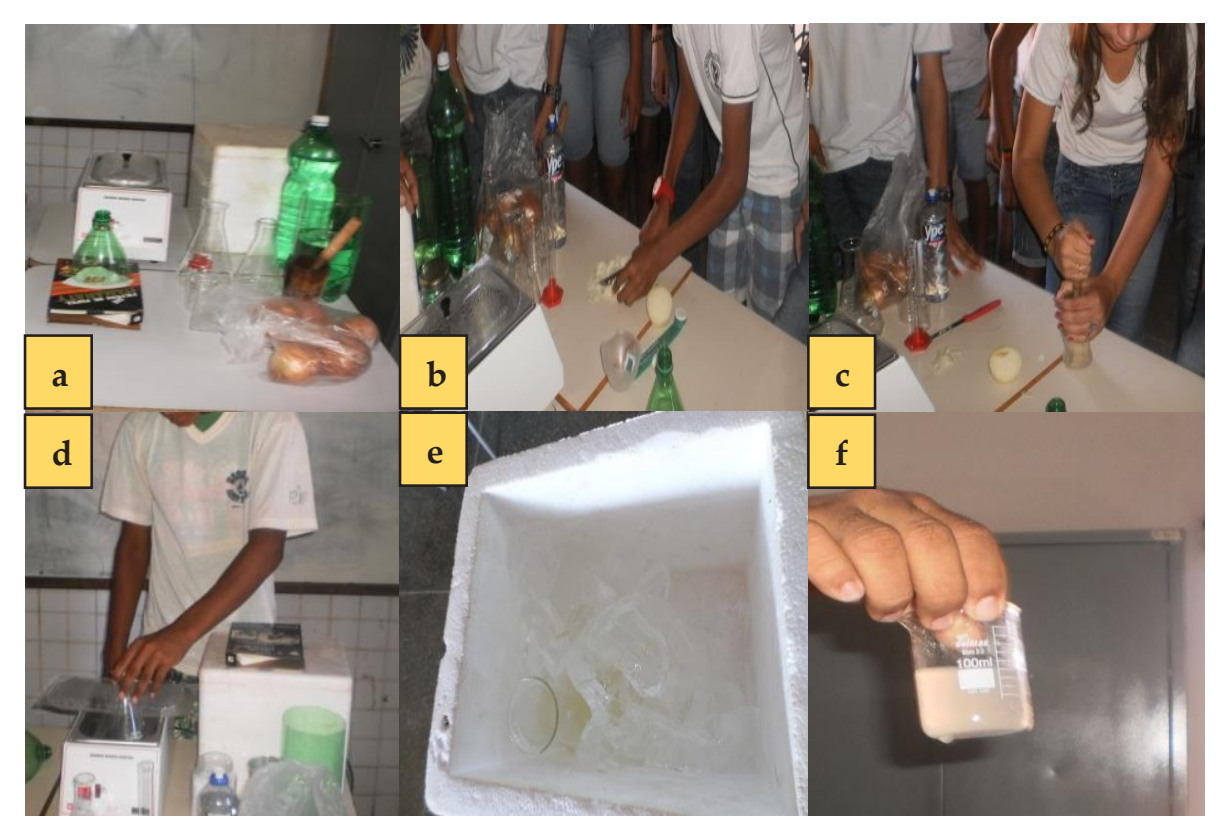

Figura 2 - a) Material; b e c) Alunos picando e triturando a cebola; d) Banho maria; e) Banho de gelo e f) observação

\subsection{Dinâmica 4: Baralho genético}

Aplicou-se o baralho genético (Figura 3), com a finalidade de incentivar os alunos a formarem trincas de bases nitrogenadas, onde os alunos receberam nove cartas, codificadas com as letras das quatro bases, sendo uma base por cada carta, e quem formou mais trincas venceu o jogo. Sendo que o baralho é formado de sessenta cartas, com mais três cartas em branco, e quem tirasse alguma carta em branco estava fora da rodada. 


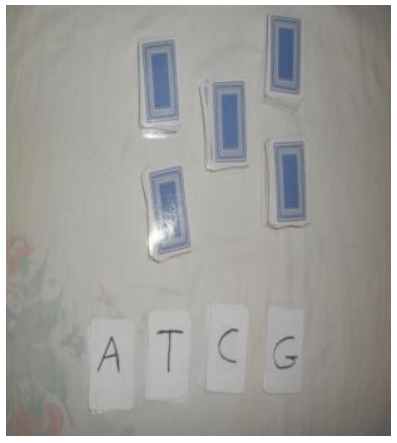

Figura 3 - Baralho genético

\section{Resultado e discussão}

Observou-se que poucos alunos tinham a ideia do que era os alimentos transgênicos. Os alunos se mostraram intrigados com o assunto, e interagiram de forma satisfatória, com questionamentos e expondo dúvidas, que foram sanadas com debates e discussões, e uma interação aluno-professor foi criada, proporcionando o processo de construção do conhecimento. Eles aprenderam que determinada característica pode ser transmitida por gerações, sendo algumas mais evidentes que outras.

Estes conceitos ajudaram os alunos a entenderem como os transgênicos são formados, e também os deixaram surpresos por saberem que os OGMs já fazem parte de suas vidas, não só na alimentação, mas também nas roupas e em alguns remédios.

\subsection{Aplicação de questionário}

Como resultado da opinião dos alunos sobre a utilidade dos transgênicos, observou-se que a maioria dos alunos não conheciam o assunto (Figura 4).

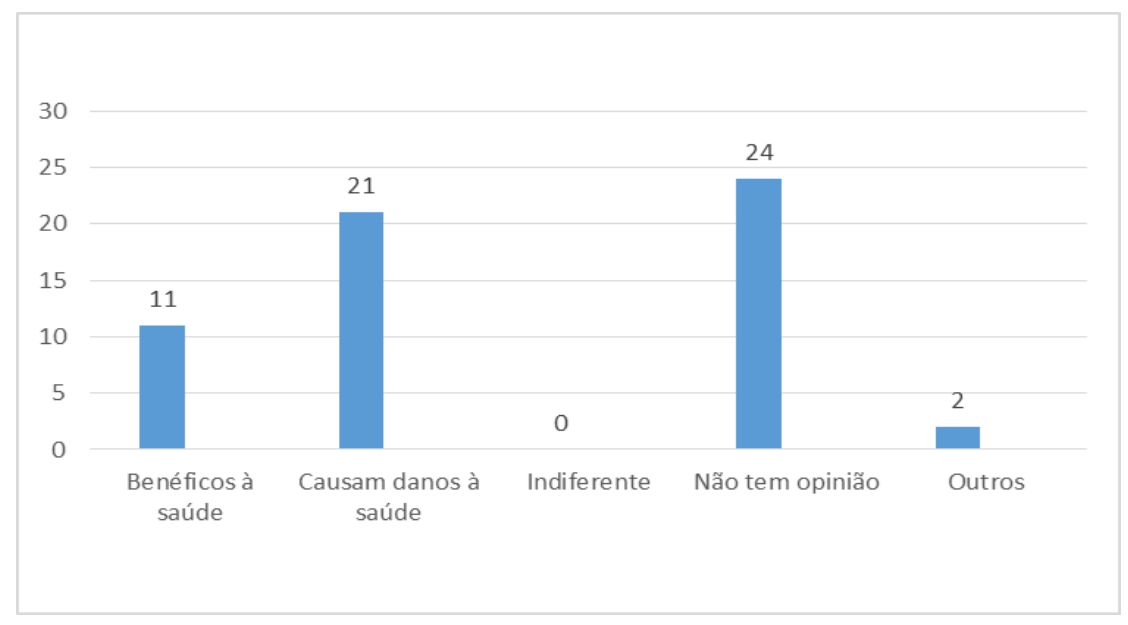

Figura 4 - Gráfico das respostas dos alunos sobre a utilidade dos transgênicos

Para Delizoicov (2009), as Ciências naturais não são formadas por um conjunto de informações explicadas e definidas, para obtenção de resultados, o seu ensino deve partir do conhecimento prévio que o aluno possui, pois este é considerado como sujeito do conhecimento

Nas demais questões, sobre o conhecimento prévio dos alunos, também foi verificado muitas dúvidas sobre os transgênicos (Tabela 1). 
Tabela 1. Respostas dos alunos com relação aos questionamentos sobre os transgênicos

\begin{tabular}{cccc}
\hline Questão & \multicolumn{3}{c}{ Respostas } \\
\cline { 2 - 4 } & Sim & Não & Sem opinião \\
\hline transgênicos? & 19 & 39 & ----- \\
\hline Você acompanha notícias vinculadas sobre os alimentos & & & \\
\hline Você concorda com o aumento de recursos, destinados à & 28 & 15 & 15 \\
pesquisa científica no Brasil, envolvendo alimentos transgênicos? & & & \\
\hline Você é a favor da rotulagem de alimentos transgênicos? & 32 & 11 & 15 \\
\hline A utilização de sementes transgênicas afeta o ambiente? & 22 & 24 & 12 \\
\hline Você concorda com a utilização de alimentos transgênicos na ração & 27 & 17 & 14 \\
para animais? & & & \\
\hline
\end{tabular}

Ancorado nesta ideia pode-se afirmar que os professores devem averiguar o conhecimento prévio do aluno, a fim de construí-lo de forma gradual, só então pode-se praticar a pedagogia libertadora que Paulo Freire (2005) nos fala, não oferecendo uma educação depositária ou com a ideia de apenas transferir o conhecimento, mas trabalhando de forma dialógica:

Desta maneira, o educador já não é o que apenas educa, mas o que, enquanto educa é educado, em diálogo com o educando que ao ser educado também educa. Ambos, assim se tornam sujeitos do processo em que crescem juntos e em que os "argumentos da autoridade" já não valem. Em que, para ser-se, funcionalmente, autoridade, se necessita de estar sendo com as liberdades e não contra elas (FREIRE, 2005, p. 79).

\subsection{Aulas}

O aproveitamento das aulas teóricas e práticas pode ser notado pelos resultados observados nas respostas dos alunos durante as atividades.

\subsection{Dinâmica 1: Quebra cabeça}

Na primeira atividade utilizando o quebra-cabeça, o desenvolvimento foi satisfatório. A todo o momento, os alunos, perguntavam se com aquela característica que foi transmitida, faria com que o organismo perdesse a sua identidade deixando de ser o que era antes. Por exemplo, eles quiseram transmitir a característica sabor da banana, para a maçã, mas quando questionados se o sabor da banana faria a maçã mudar de forma física ou de cor, eles afirmaram que isto não poderia ocorrer, pois somente a característica do sabor da banana havia passada, e não todo conjunto de características do DNA da banana, evidenciando que o trabalho nas aulas teóricas havia sido assimilado de forma satisfatória.

Para Vygotsky (2007), a construção de conceitos se dá por níveis diferentes de desenvolvimento, ou seja, se divide em duas fases distintas: o nível de desenvolvimento real, onde a criança desenvolve as funções mentais amadurecidas e o desenvolvimento potencial, onde a criança ainda necessita que um adulto ajude a relacionar tarefas um pouco mais difíceis, ele chama isso de Zona de Desenvolvimento Proximal, ou ZDP. De acordo com esta ideia, procurou-se com as atividades práticas transportar os 
alunos do abstrato para o real, onde a construção do conhecimento se torna possível através da experimentação e da proximidade do abstrato com o real.

\subsection{Dinâmica 2: Estrutura de DNA com jujubas}

A dinâmica da montagem da estrutura de DNA com jujubas foi muito bem realizada pelos alunos do $9^{\circ}$ e $8^{\circ}$ ano, porém com o $7^{\circ}$ ano não se obteve resultado satisfatório, pois alguns alunos, mesmo com ajuda, tiveram dificuldades em montar a cadeia de DNA. Com esta atividade os alunos puderam observar como é a forma helicoidal da estrutura do DNA (Figuras 5 a e b). Outro fato que ajudou na compreensão da formação da estrutura da substância foi a utilização de jujubas coloridas, que auxiliaram na observação das bases nitrogenadas e suas ligações.

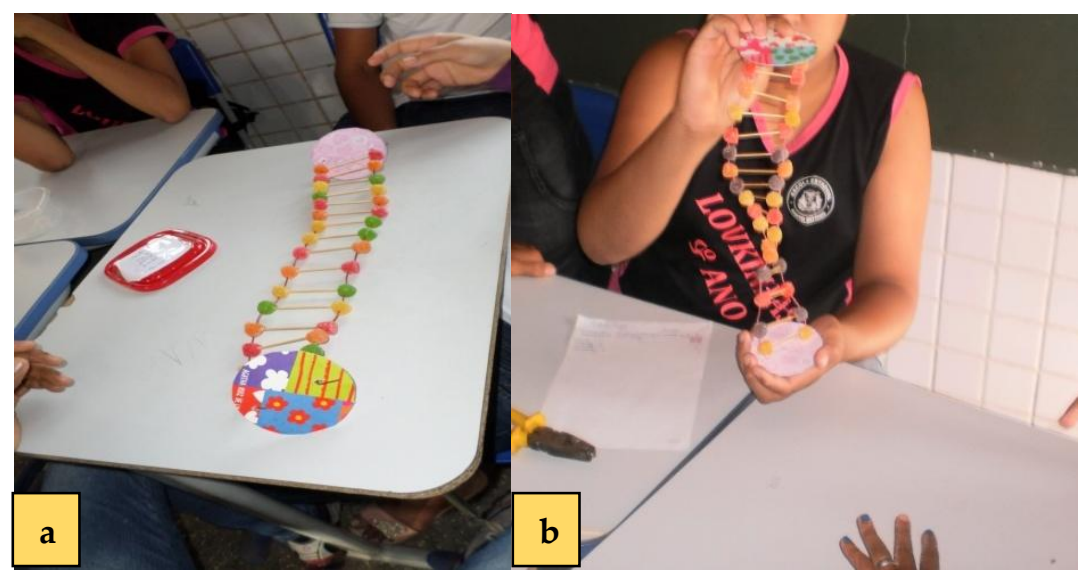

Figura 5 - a) Montagem da estrutura do DNA utilizando jujubas; b) Noção da forma helicoidal da molécula de DNA

\subsection{Dinâmica 3: Extração do DNA da cebola}

Com o experimento da extração do DNA da cebola, os alunos observaram e tiveram noção do arranjo da estrutura do composto (representados pelos grumos contidos na mistura obtida no béquer, após o choque térmico). Para o sucesso desta atividade foi primordial a colaboração dos alunos, desde a maceração da cebola, até a mistura dos ingredientes. A cada passo do processo, era demonstrado a importância de cada etapa da metodologia, desde o ato de picar a cebola, até a importância do choque térmico, para o sucesso da atividade.

A experiência chamou a atenção dos alunos, pois pode ser feita em casa com materiais simples. Desta maneira os alunos puderam visualizar na prática, através de um ensaio simples, que a ciência pode ser palpável, com isso saindo do campo do abstrato para a verificação in loco.

Durante a experimentação científica, se torna de extrema importância o diálogo em cada momento de prática, no intuito de que o aluno possa desenvolver seu senso crítico e forma de observação dos fenômenos. Driver et al. (1994) ressaltam que pensar sobre as próprias ideias ajuda os alunos a se tornarem conscientes de suas concepções alternativas ou ideias informais.

O simples ato de transmitir conceitos científicos não é o suficiente para garantir um ensino de Ciências que seja capaz de contribuir no desenvolvimento do aluno, para exercer de forma correta sua cidadania, muito menos para instigá-lo a ser um intelectual crítico. Freire (2005) ressalta que esse tipo de educação denomina-se" bancária", e só serve na contribuição de uma alienação e ainda por cima aumenta o sufoco das classes dominadora sobre a classe dominada.

\subsection{Dinâmica 4: Baralho genético}

A atividade com as cartas foi bem recebida pelos alunos, que se mostraram instigados por este material, pois além de aprenderem, também se divertiram muito, deixando a aula muito mais leve. 
Notou-se, deste modo que, o que foi trabalhado nas aulas teóricas teve assimilação satisfatória e durante a atividade, as perguntas dos alunos eram direcionadas ao tema, e em nenhum momento tiveram dificuldades em executar a atividade proposta, satisfazendo as expectativas esperadas.

Os jogos como recursos didáticos alternativos, auxiliam no processo de ensino aprendizagem de forma positiva, pois fazem com que os alunos interajam e se descontraiam colocando a mente em funcionamento para obter novos conhecimentos, sem constar no fato de que esse tipo de recurso integra o aluno com o professor. Conforme relatado por Macedo, Petty e Passos (2000), firmando uma relação entre jogo e conhecimento, pode-se assegurar que, para adquirir conhecimento e jogar é preciso agir.

\section{Conclusões}

A escola é o campo ideal para se discutir assuntos de relevância social que promovam, ou possam vir a promover mudanças na vida das pessoas.

Trabalhando nessa perspectiva, nota-se que assuntos como DNA e formação dos alimentos transgênicos, podem ser discutidos nas escolas, dentro do ensino fundamental.

Com os resultados das atividades, verificou-se que os alunos se envolveram de forma significativa, com as aulas teóricas, práticas e dinâmicas propostas, tornando o aprendizado mais prazeroso, e com certeza sendo eficaz na construção do conhecimento.

Os alunos precisam, desde cedo, serem inteirados de assuntos polêmicos, pois se encontram em uma fase de descoberta em que sua opinião critica está sendo formada.

Com dialogicidade, aliada a um bom método de ensino, pode-se alcançar índices satisfatórios de aprendizagem, principalmente no estudo das Ciências naturais.

Porém uma interdisciplinaridade mais eficaz se faz necessária para que se possa ter realmente, um aprendizado de qualidade no ensino fundamental, refletindo-se posteriormente nos anos seguintes, diminuindo a evasão escolar no ensino médio e dando oportunidade aos alunos de ingressar em uma boa instituição de ensino superior.

\section{Agradecimentos}

Ao IFMT - Campus São Vicente, pelo apoio no projeto e à escola estadual Santo Antônio por ter liberado o acesso aos seus estudantes; e à Coordenação de Aperfeiçoamento de Pessoal de Nível Superior (CAPES) pelo subsídio através do Programa de Consolidação das Licenciaturas (PRODOCENCIA) Edital 019/2013, processo № 113.657, e do Programa Institucional de Bolsa de Iniciação à Docência (PIBID) Edital № 061/2013, processo № 128.570, IFMT/Campus São Vicente/Sub Projeto Ciências.

\section{Referências}

ALMEIDA, Gustavo Calixto Scoralick de e LAMOUNIER, Wagner Moura. Os alimentos transgênicos na agricultura brasileira: evolução e perspectivas. Organizações Rurais \& Agroindustriais. Lavras, v. 7, n. 3. P. 345-355, 2005.

AZEREDO, R. M. A. Biotecnologia e segurança alimentar - Saiba como o DNA pode enriquecer os alimentos. São Paulo: Nobel, 2003. Cap. 1.pag. 13-31.

BRASIL. Decreto n. ${ }^{\circ}$ 4.680, de 24 de abril de 2003. Regulamenta o direito à informação assegurada pela Lei n.. 8.078 , de 11 de setembro de 1990, quanto aos alimentos e ingredientes alimentares destinados ao consumo humano ou animal que contenham ou sejam produzidos a partir de organismos geneticamente modificados, sem prejuízo do comprimento das demais normas aplicáveis. Diário Oficial, Brasília, DF, 24 de abril de 2003. 
DELIZOICOV, Demetrio. Ensino de ciências: fundamentos e métodos. $3^{a}$ edição. São Paulo: Cortez 2009.

DRIVER, R., SQUIRES, A., RUSHWORT, P. e WOOD-ROBINSON, V. Making Sense off Secondary Science: Research into Children's ideas. London: Routledge, 1994.

FREIRE, Paulo. Pedagogia do Oprimido. Rio de Janeiro: Paz e Terra, 2005.

LAURENCE, J. Biologia: Ensino Médio. Volume único. 1. edição. São Paulo: Nova Geração, 2005.

MACEDO, L., PETTY, A. L. S. e PASSOS, N. C. Aprender com jogos e situações-problemas. Porto Alegre: Artmed, 2000.

MARTINS, M.A.G. Ciência, tecnologia e sociedade: o desafio da interação. Resenha Cadernos de Ciência \& Tecnologia, Brasília, v. 20, n. 1, p. 183-190, 2003.

MASCARENHAS, Camila Freres Dorotheu; STIPP, Nilza Aparecida Freres; CAMPOS, Ricardo Aparecido; STIPP, Marcelo Eduardo Freres. Organismos geneticamente modificados: uma abordagem sob a ótica do Direito Ambiental. Geografia (Londrina), v. 21, n. 3.p. 23-39, set/dez. 2012.

MENDONÇA, Ana Cláudia Cayres de. Transgênicos: opinião de professores e alunos de nível médio da área. Dissertação (Mestrado) - Escola Superior de Agricultura Luiz de Queiroz. Piracicaba, 2005. p. 80 .

MONQUERO, Patrícia Andréa. Plantas transgênicas resistentes aos herbicidas: situação e perspectivas. Bragantia, Campinas, v.64, n.4, p.517-531, 2005.

Organização das Nações Unidas (ONU). Relatório: “Perspectivas da População Mundial: Revisão de 2012. Disponível em: <http://www.onu.org.br>. Acesso em setembro, 2013.

PARÂMETROS CURRICULARES NACIONAIS (PCN): Ciências naturais (1. a a 4 . $^{\text {a }}$ série). Brasília: MEC: SEF, 1997. V. 4.

PINHEIRO, N. A. M.; MATOS, E. A. S. A. e BAZZO, W. A. Refletindo acerca da ciência, tecnologia e sociedade: enfocando o ensino médio. Revista Iberoamericana de Educación, Madrid, n. 44, 2007. Disponível em: <http://www.rieoei.org>. Acesso em: 20 setembro. 2013.

RIDLEY, Mark. Evolução. 3. edição. Porto Alegre: Artmed, 2006.

ROSA, Carlos Augusto de Proença. História da ciência: a ciência e o triunfo do pensamento científico no mundo contemporâneo. Carlos Augusto de Proença. 2. ed. Brasília: FUNAG, 2012.

VALOIS, R. F., ZUELIG, K. J., HEUBER, E. S. e DRANE, J. W. Relationship between perceived life satisfaction and dieting behavior among public high school adolescentes. Eating disorders: The jornal of treatment and prevention, 11, 271-288, 2003.

VYGOTSKY, Lev Semenovich. A formação Social da Mente. Martins Fontes. $7^{\text {ạ }}$ edição. São Paulo 2007. 